\title{
POLISH AND HUNGARIAN HISTORICAL TRADITION IN THE HUNGARIAN-POLISH CHRONICLE
}

\author{
Ryszard Grzesik http://orcid.org/0000-0001-7887-6895
}

Polish Academy of Sciences, Institute of Slavic Studies

\begin{abstract}
The aim of the article is to present two written traditions which are discernible in the HungarianPolish Chronicle. One of them is of the Hungarian and the other one of the Polish origin. The Legenda sancti Stephani regis by Bishop Hartvich is one of them. It is also the simplest one to analyse. The text comparison shows that it could be regarded as the shorter text variant which served as the story basis for the chronicler, similarly to the text from the Seitz manuscript dated back to the second half of the $14^{\text {th }}$ century. One of the variants of the now lost Gesta Ungarorum could be a source of information on the ancient history of Hungarians. One can observe traces of using a written source of the Polish origin as well. It could be a narrative form dating back to the beginning of the $13^{\text {th }}$ century, in which the remnants of another, older text - possibly from the time of Bolesław II Large (the second half of the $11^{\text {th }}$ century) - could be found.
\end{abstract}

Keywords: Hungarian-Polish Chronicle, medieval chronicles, Hungarian-Polish cultural relationship.

The conference about the Polish and Hungarian relationship would be incomplete without a mention of a narrative which connects historical traditions of both countries. It was obvious for the rubricator of the oldest manuscript, the ZamoyskiCode from the mid-14 $4^{\text {th }}$ century, who entitled it Incipit Cronica Vngarorum iuncta et mixta cum cronicis polonorum et uita sancti stephani. ${ }^{1}$ The present title of the Chronicle, The Hungarian-Polish Chronicle, is used from the mid- $19^{\text {th }}$ century. ${ }^{2}$ We

1 Chronica Hungaro-Polonica, pars 1. (Textus cum varietate lectionum), ed. B. Karácsonyi, Szeged 1969 (Acta Historica Universitatis Szegedensis de Attila József nominatae, vol. 26) [in the following: HCP], p. 9; M. Homza, Uhorsko-pol'ská kronika. Nedocenený prameň k dejinám strednej Európy, Bratislava 2009, Appendix, p. I.

2 Hipolit Kownacki, the first modern editor, called it The Hungarian Chronicle, Kronika wegierska na początku wieku XII. Kronika czeska na początku wieku XI, w tacińskim języku pisane: z tłomaczeniem 
can be almost sure, after the discussion lasting almost 200 years, that the Chronicle was composed on the Slavonian court of Coloman, the former king of $\mathrm{Halich}^{3}$ at the turn of the 1230s. ${ }^{4}$ It described the Hungarian history from the very origins of the Hungarians in East Hungary (ad orientalem regionem vngarorum) ( $^{5}$ until the mention of the miracles of St Stephen ${ }^{6}$ after his elevation by King Ladislas. ${ }^{7} \mathrm{Nev}-$ ertheless, all its manuscripts are known only from Polish libraries. Its text can be classified into two text variants: the longer one, which concentrates on the secular, political history and the shorter one, belonging to the hagiographical family of lives of St Stephen. One can suspect that both reflected the lost archetype, which could have been transferred from Hungary to Poland by Salomea, Coloman's widow returning to Lesser Poland after her husband's tragic death during the Tatar incursion of Hungary in 1241. Thanks to this transfer, the Polish historical tradition is enriched with some motifs of the Hungarian historical tradition, such as the Polish-Hungarian rivalry for the crown. ${ }^{8}$

na Polski język. Tudzież Ziemopismo Bedy wieku VIII. List popa Jana wieku XIII z rękopismow rożnych bibliotek [ed. by H. Kowna cki], Warsaw: Drukiem N. Glucksberga, Księgarza i Typografa Królewskiego Warszawskiego Uniwersytetu, 1823. Also Stephanus Ladislaus Endlicher knew the narrative as Chronica Hungarorum, S.L. Endlicher, Rerum Hungaricarum Monumenta Arpadiana, Sangalli: Scheitlin \& Zollkofer, 1849, p. 60. Michał Wiszniewski wrote about Kronika Wegierska i Polska, M. Wiszniewski, Historya literatury polskiéj, vol. 2, Cracow: W drukarni Stanisława Gieszkowskiego nakładem autora, 1840, p. 94. Stanisław Pilat in his edition in Monumenta Poloniae historica [in the following: MPH] used the contemporary form: Kronika wegiersko-polska, ed. S. Pilat, MPH, vol. 1, Lwów 1864, p. 485.

3 Coloman, a middle son of Andrew II lived between 1208 and 1241. Thanks to the agreement with Poland (Leszek the White of Cracow) in Spiš in 1214 he was married to Leszek's daughter, Salomea and was crowned for King of Halich. From 1220s he was a Duke of Spiš and from 1226 Duke of Slavonia. He was hardly wounded in the battle against the Tatars at Muhi and afterwards he died. T. Almási, "Kálmán (2.)" [in:] Korai magyar történeti lexikon (9-14. század), eds. Gy. Kristó, P. Engel, F. Makk, Budapest 1994 [in the following: KMTL], p. 316; M. Font, G. Barabás, Koloman, King of Galicia and Duke of Slavonia (1208-1241), Amsterdam 2019.

4 But recently J. Csákó, A Magyar-lengyel krónika és a hazai elbeszélő hagyomány, Századok, vol. 148 , no. 2. 2014, p. 310 , advocates for Poland as a place of the Chronicle's origin, in the milieu of the Hungarian princesses, Kinga and Jolanta.

5 HPC, p. 9, M. Homza, Uhorsko-pol'ská kronika. Nedocenený, p. I.

${ }^{6}$ St Stephen (ca. 970 - 15. August 1038), the first King of Hungary, founder of the Christian Hungarian monarchy, from 1083 Patron Saint of the state. Gy. Györffy, István király és müve, Budapest 1977 (and next eds. 1983, 2001); Gy. Györffy, König Stephan der Heilige, Budapest 1988; Gy. Györffy, King Saint Stephen of Hungary, New York 1994; Gy. Kristó, M. Jáno si, István (I.), in: KMTL, pp. 291-292.

7 St Ladislas (ca. 1040-1095) was a younger son of Béla I. He was educated in Poland and was perceived as a Pole by contemporaries. He was a King in the years 1077-1095. Athleta Patriae. Tanulmányok Szent László történetéhez, ed. L. Mezey, Budapest 1980 (Hungaria Sacra, 1); F. Makk, M. Jánosi, László (I), in: KMTL, pp. 394-396.

8 R. Grzesik, Kronika węgiersko-polska. Z dziejów polsko-węgierskich kontaktów kulturalnych w średniowieczu, Poznań 1999, pp. 93-129; idem, "Attyla a Słowianie. Przyczynek do wyobrażenia o kontaktach huńsko-słowiańskich w średniowiecznych źródłach narracyjnych," Roczniki Historyczne 1993, vol. 59, pp. 39-41 and idem, "Etnogeneza Słowian w polskich kronikach średniowiecznych," Slavia Antiqua 2020, vol. 61, p. 45 (possible influence of Attila story of the Hungarian-Polish Chronicle for the development of the Silesian-West Pomeranian Attila tradition). 
As we can see from the manuscript's title, the Chronicle is a mixture of both historical traditions derived from three sources. The Legenda Hartviciana is one of them, and it is the easiest to identify. It was the Life of St Stephen, the first King of Hungary and Patron Saint of this state. This fact is so obvious that the first editor, Hipolit Kownacki, ${ }^{9}$ included even the Hartvich's preface to the Legend in his edition of the Chronicle, thinking that the hagiographist is the author of the Chronicle and that the Preface was originally written for the Chronicle. The Hartvich's Preface was reedited by Stephanus Ladislaus Endlicher ${ }^{10}$ and only therefore we know that he published the Chronicle's text using the Kownacki's edition and not the manuscript, despite his proud note: E codice Warsaviensi saeculo XIII. ${ }^{11}$ But Legenda was preserved in several manuscripts, which were classified in some families by the earned editor of the Legends of St Stephen in Scriptores rerum Hungaricarum, Emma Bartoniek. A question arose, which manuscript, or rather the text variant could be the textual basis of our Chronicle?

The Code No. 17 of the State Széchényi Library in Budapest seems to be the oldest manuscript of the Legenda Hartviciana. It was written in beautiful Carolingian minuscule probably already in the $12^{\text {th }}$ century. It is known under the signature B1. Not so much younger seems to be the manuscript of the Cistercian monastery in Reun, which was written at the beginning of the $13^{\text {th }}$ century, abbreviated as R. Manuscript B1 was a basis of a larger part of editions, mainly the older ones. However, Emma Bartoniek mentioned that this manuscript, despite its antiquity, transmitted the erroneous text and she believed that the manuscript $\mathrm{R}$ is better. Her canonical edition of Legenda Hartviciana is in fact the edition of the Reun Code.

There is a group of younger manuscripts, and two of them can be interesting for us in the context of the Hungarian-Polish Chronicle. One is a manuscript of Austrian National Library in Vienna, No. 3662 from the Benedictine monastery in Mondsee and another is a manuscript of the Bavarian State Library in Munich, No. 18624 from the Benedictine monastery in Tegernsee - both originate from the end of the $15^{\text {th }}$ century. We can define this group as a Benedictine branch of a legendary tradition. Both manuscripts transmitted almost the same text and one may suspect that one of them served as a basis for another. Emma Bartoniek thought that it was this manuscript branch which served the chronicler as a basis for his work. ${ }^{12}$ However, my analysis

9 Tymoteusz Hipolit Kownacki (1761-1854) was an amateur editor of sources. He translated the Hungarian-Polish Chronicle to a modern language (Polish) as a unique until the $21^{\text {st }}$ century. His translation was written in archaic language, hard to read for contemporary reader. A. Birken majerówna, "Kownacki Tymoteusz Hipolit" [in:] Polski stownik biograficzny, ed. E. Rostworowski, vol. 14, WrocławWarszawa-Kraków 1968-1969, pp. 584-587.

${ }_{10}$ Stephan Ladislaus Endlicher(1804-1849) was an Austrian historian and botanist, the editor of sources. Österreichisches Biographisches Lexikon, vol. 1, Wien 1956, p. 249, www.biographien.ac.at/oebl/oebl_E/ Endlicher_Stephan-Ladislaus_1804_1849.xml;internal\&action=hilite.action\&Parameter=Endlicher [accessed: January 20, 2020].

11 H. Kownacki, Kronika, pp. VIII-IX, 1-4; S.L. Endlicher, Rerum Hungaricarum, p. 60 and commentary by S. Pilat, MPH, vol. 1, p. 494.

12 "Legenda sancti Stephani regis maior et minor atque Legenda ab Hartvico episcopo conscripta," ed. E. Bartoniek [in:] Scriptores rerum Hungaricarum, ed. E. Szentpétery, vol. 2, Budapestini, 1938, p. 374. 
of the text variations in the SRH edition did not confirm this opinion. In conclusion of my research I stated that the chronicler used an unknown manuscript which was similar to the oldest manuscripts B1 and R, but the Chronicle abbreviated this basic version. ${ }^{13}$

I did not know that this problem was already solved at the time of my research. The earned review devoted to the Hungarian source criticism and auxiliary sciences, Magyar Könyvszemle, published an edition of the hitherto unknown manuscript of Legenda Hartviciana by László N. Szelestei. ${ }^{14}$ It was a text from the Carthusian Legendary from Seitz from the second half of the $14^{\text {th }}$ century. The Legendary originated in the Pauline monastery at Lövöld, founded by Louis the Great, but some years after the monks accepted the Carthusian rule and left Lövöld with their library for Styrian Seitz. The text of the Legend is abbreviated and similar to that of the Hungarian-Polish Chronicle, but also is close to the variants of B1 and R. The author suggested that both narratives could be classified as a shorter version of the Legenda Hartviciana. ${ }^{15}$ I agree with this opinion, which develops my previous argumentation. ${ }^{16}$ Now I have been preparing for several years a new Latin-Polish edition of Legends of St Stephen, concentrating my attention on the Legenda Hartviciana and including the shorter text-version. ${ }^{17}$

Vita sancti Stephani was not the only Hungarian source of the Chronicle according to the manuscript's title. The Chronica Ungarorum was the first narrative mentioned by the rubricator. There is no doubt that it was one of the versions of the lost Hungarian basic source, which was since Bálint Hóman's time named Gesta Ungarorum. In my analysis I tried to prove that it was one of the transcriptions of this lost narrative. Judit Csákó proved recently that it was rather a version from the beginning of the $13^{\text {th }}$ century than an earlier one. I can accept this conclusion because it stay not in opposition to philological analysis of words and expressions, used by the Hungarian-Polish Chronicle and by other Hungarian chronicles to describe the new homeland of the Hungarians or the events from the civil war after St Stephen's death. ${ }^{18}$ Maybe it is worth to correct my error mentioned by J. Csákó. I interpreted

13 R. Grzesik, Kronika, pp. 44-45, 50-51.

14 L.N. Szelestei, "A seitzi legendárium Szent István-legendája,” Magyar Könyvszemle 1991, pp. $1-19$.

15 Ibidem, p. 3.

16 J. Csákó, A Magyar-lengyel krónika, pp. 305-306 and 334 (English resume) accepted my previous opinion and opposed it to L.N. Szelestei's suggestions. According to me there is no contrary between them, the discovery of Seitz-text completes my arguments.

17 I expressed my opinion on the two versions of the Hartvich's Legend for the first time during the conference in Oxford in 2012. Unfortunately, I have no information about the fate of the conference text, which I gave for publishing to the organizers. Cf. R. Grzesik, "Tradycja tekstowa i rękopiśmienna Legend św. Stefana,” Nasza Przeszłość 2016, vol. 125, pp. 127-145. I prepared the edition in the framework of an exchange common programme of the Polish Academy of Sciences and the Hungarian Academy of Sciences in the years 2010-2016 as the project I 6 together with Dr László Veszprémy and Prof. Anna Kotłowska. Now it is a statute programme of the Institute of Slavic Studies, Polish Academy of Sciences.

18 R. Grzesik, Kronika, p. 75; J. Csákó, A Magyar-lengyel krónika, pp. 316-332, 334 (resume). However, on p. 320 she refused my philological analysis proving that the similarities in the presentation 
the phrase palus Albe regis ${ }^{19}$ defining a place where King Alba or rather Aba Samuel died, as a place in contemporary Budapest, at former Rákos field, where I found two streets with the same name: Aba utca. My premise was that he had to die close to Pest (prope petsth). ${ }^{20}$ However, it was obvious to the Hungarian medievalist that it was a monastery of Abasár, where the real King Aba Samuel was buried. The place means exactly: 'the marshes of King Aba.' ${ }^{21}$

The narration of a Hungarian history began from a long passage about the way of Old-Hungarians from the Eastern Hungary through the whole Europe to Sclavonia and Ungaria, where their state was created. It was a fabulous story of their King, which could be composed using both oral and written traditions. ${ }^{22}$ No historian doubted that it was a story of Attila, as this name figures also in the manuscripts of the shorter version of the Chronicle. ${ }^{23}$ Nevertheless, his name was changed into Aquila in the longer version. I had problems to decide which version of the name was proper for the Chronicle and occurred in the archetype. ${ }^{24}$ Now I am sure that it was the story of Aquila from the very beginning and the form Atyla in the shorter version is an erudition correction of the copyist. The same opinion was expressed by Martin Homza, who devoted a long fragment to Aquila in his edition of the Hungarian-Polish Chronicle $^{25}$. He analysed this person in the spirit of culture anthropology and Slavic romanticism as a literary person who represented physical force of conquering the land, who married the local Slavic princess and who was the instrument of the God's Providence. I do not feel competent to comment on so symbolic meaning of this person. For me, it is obvious that his name was created to prove that he was a city founder. He founded Aquileia, called the city after him, in contrary to real Attila, who destroyed this important city and Church metropolis. Therefore, the first King of Hungary had to have such a name. ${ }^{26}$

I believe that the story of Aquila represents one of the earlier stages of creating of the Attila and Hun tradition, which started to be one of the basic factors of the Hun-

of a new land in several chronicles was only a question of literary topoi. However, these topoi had to be known to the chronicler, who read Chronica Ungarorum and used it.

19 HPC, p. 65.

20 HPC, p. 65.

${ }_{21}$ R. Grzesik, Kronika, p. 180 n. 747 (to p. 179); J. Csákó, A Magyar-lengyel krónika, p. 326. Cf. Gy. Györffy, Az Árpád-kori Magyarország történeti földrajza, vol. 3, Budapest 1987, pp. 50, 130; B. Kovács, "Abasár" [in:] KMTL, p. 27.

22 The whole narration seems to sound as a saga recited near the fire.

23 HPC, p. 14. New manuscripts of the shorter version of the Hungarian-Polish Chronicle were discovered by Stefan Albrecht: S. Albrecht, "Drei neue Handschriften des sog. Chronicon hungaricopolonicum," Studia Źródłoznawcze 2015, vol. 53, pp. 111-121; idem, “Three New Manuscripts of the so Called Chronicon hungaro-polonicum," Hungaro-Polonica: Young Scholars on Medieval PolishHungarian Relations, eds. D. Bagi, G. Barabás, Zs. Máté, Pécs 2016, pp. 119-141.

24 R. Grzesik, Kronika węgiersko-polska, pp. 171-172; idem, Hungaria - Slavia - Europa Centralis. Studia z dziejów kultury środkowoeuropejskiej we wczesnym średniowieczu, Warszawa 2014, p. 65 and n. 166.

25 M. Homza, Uhorsko-pol’ská kronika, pp. 50-58.

26 Ibidem, p. 51. By the way, it was the beginning of a great career of Venice, founded by Aquileian refugees. 
garian self-consciousness from the end of the $13^{\text {th }}$ century and which was recently described by László Veszprémy. ${ }^{27}$ The narration of the Chronicle is richer than that of the Anonymous Notary. Nevertheless, there is no name of the Huns, Aquila was presented as the conqueror of Pannonia and ancestor of the Arpadians. Martin Homza introduced even the name: Aquilovci = the Aquilas for the description of the Hungarian royal dynasty in the context of the Chronicle. ${ }^{28}$

The battle in Croatia is an important event in Aquila's life. He was sent there by God to revenge the murdered King. The name of the ruler is also the subject of dispute. The longer redaction has the popular name of the Polish rulers, Kazimir $=$ Kazimierz. But the shorter version transferred the previous name Trezimir to us ${ }^{29}$ which one can interpret as a popular Croatian name, Krešimir. The King was murdered by the subjects, who rebelled against him shouting that they do not want to have a ruler over them. It was in Sclavonia, where Aquila with the Hungarians defeated the Slavs and Croats. It was the first stage of the Hungarian settlement on the Danube and Tisza. This story is similar to that of King Zvonimir, written in the Croatian version of the Chronicle of Dioclea. I tried to interpret this story as a very early stage of the development of this legend, when it was not connected with the name of Zvonimir yet. ${ }^{30}$ I think that newer remarks of Dražen Nemet support my ideas. ${ }^{31}$ Martin Homza analysed the story deeper and interpreted it as a reflex of the old Great-Moravian tradition about the fall of the state. ${ }^{32} \mathrm{I}$ think he can be right. This tradition of the rebel against the ruler and his death could reflect the real events from the time of final crisis of Great-Moravian State and could be preserved in one of the Benedictine monasteries of the Slavic liturgy and after centuries included into the Croatian and the Hungarian historical tradition. This would support my thesis that the whole Chronicle was written in Slavonia.

27 L. Veszprémy, "A magyarországi hun hagyomány legkorábbi írott forrásai és európai kapcsolatuk," Acta Historica Universitatis Szegedensis de Attila József nominatae 2013, vol. 135, pp. 25-44.

28 L. Veszprémy, A magyarországi, p. 41, M. Homza, Uhorsko-polská kronika, p. 210 (index).

29 HPC, p. 17.

30 R. Grzesik, Kronika, pp. 82-90; idem, "Sources of a Story About the Murdered Croatian King in the Hungarian-Polish Chronicle," Povijesni Prilozi 2003, Y. 22, vol. 24, pp. 97-104.

31 D. Nemet, "Smrt hrvatskog kralja Zvonimira - problem, izvori i tumačenja," Radovi Zavoda za hrvatsku povijest u Zagrebu 2006, vol. 38, pp. 73-91, www.ffzg.unizg.hr/pov/pov2/files/3zavod/ radovi38/nemet38.pdf [accessed: March 22, 2019].

32 M. Homza, Uhorsko-pol'ská kronika, pp. 54-55; M. Homza et al., Svätopluk v európskom pisomníctve. Śtúdie z dejín svätoplukovskej legendy, Bratislava 2013, pp. 58. Valuable is his remark that some information about Svätopluk was preserved in the Chronicle of Dioclea (ibidem, pp. 58, 125-140); cf. and my observations about the Great-Moravian tradition in Central Europe: R. Grzesik, "Great Moravia as the Basis of the Central European Medieval Historical Tradition" [in:] Slovensko a Chorvátsko. Historické paralely a vzt’ahy (do roku 1780). Slovaćka i Hrvatska. Povijesne paralele $i$ veze (do godine 1780), eds. M. Homza, J. Lukačka, N. Budak, Bratislava 2013, pp. 66-71; idem, Hungaria, pp. 63-64. 
However, Martin Homza shown Spiš as the place of the Chronicle composition and Adolf, the first known provost of Spiš, as its author. ${ }^{33}$ It is, however, an opinion without strong arguments. It is hard to imagine that any literary work would be written in the territory almost without settlements at that time, where there was no cultural milieu. That was created only after the Tatar incursion in 1241-1242, when the Hungarian Kingdom was rebuilt and the colonization action of Spiš intensified. At the end of the $13^{\text {th }}$ century it was just a place of several towns and Church cultural centres, but not earlier. The Bratislava researcher thinks that the cult of St Ursula was developed especially in Spiš, but in fact it grew in the whole territory of Hungary, parallel to the Attila tradition. ${ }^{34}$ One of the arguments for the Spiš theory is that Sclavonia of the Chronicle denoted the whole Hungarian Kingdom and was the relict of the name of Great-Moravian state. ${ }^{35}$ However, the reading of the source text let us understand this term as present-day Slavonia, a part of contemporary Croatia. ${ }^{36}$

Dániel Bagi's precious analysis of the name $S(c)$ lavonia supports me in the reading of the source. He rejects the possibility that this term could have a wider meaning in the sense of the Hungarian Kingdom. According to him, the name Sclavonia sensu largo was a culture name for the eastern pagan or early Christianized territories used by the Medieval German and Western European clerks. It was, according to him, the culture name of the same type as the Antic Barbarians. ${ }^{37}$ It seems to be probable, but one should add that the name was derived from the name of the people. They were Slavs and they probably had the consciousness of kinship to other Slavic people. Maybe the including of the Hungarians to the Slavic people by late Medieval Polish chroniclers was not the usage of the topos of the barbarians, but the result of a knowledge that the language of many inhabitants of Hungary was similar to Polish. ${ }^{38}$

33 M. Homza, Uhorsko-polská kronika, pp. 26-27; Historia Scepusii, vol. 1: Dejiny Spiša. Dzieje Spisza, eds. M. Homza, S.A. Sroka, Bratislava-Kraków 2009, pp. 290-291 (part written by M. Homza).

34 Historia Scepusii, vol. 1, p. 291 - the author underlined the Adolf's connection with the Cologne cults; G. Barna, Távolsági zarándoklatok és búcsújáró helyek az Árpád-kori Magyarországon 1991, Honismeret, vol. 19, no. 4, p. 14, http://epa.oszk.hu/03000/03018/00098/pdf/EPA03018 honismeret_1991_04_010-016.pdf [accessed: March 22, 2019]; A Tüskés, "Szent Orsolya tisztelete a középkori Magyarországon: legendák, ereklyék, oltárok," Opus Mixtum 2014, vol. 3, p. 35, https:// www.academia.edu/39754318/T\%C3\%BCsk\%C3\%A9s_Anna_Szent_Orsolya_tisztelete_a_k\%C3\%B $6 \mathrm{z} \% \mathrm{C} 3 \% \mathrm{~A} 9 \mathrm{pkori}$ Magyarorsz $\% \mathrm{C} 3 \% \mathrm{~A} 1$ gon_legend $\% \mathrm{C} 3 \% \mathrm{~A} 1 \mathrm{k} \_$erekly\%C3\%A9k_olt\% $\%$ C $3 \% \mathrm{~A} 1 \mathrm{rok}$

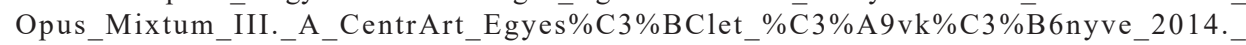
Szerk._T\%C3\%B3th_K K\% $3 \%$ A1roly._Budapest_CentrArt_Egyes\%C3\%BClet_2014_34-49 [accessed: March 22, 2019] - without knowledge of the Hungarian-Polish Chronicle.

35 M. Homza, "Pokus o interpretáciu úlohy kňažnej Adelajdy v Uhorsko-pol’skej kronike," Historický časopis 1999, vol. 47, no. 3, p. 367 n. 73 and my critical review in Studia Źródtoznawcze 2000, vol. 38, p. 126.

36 T. Bali, Slavonski meandar. Prostor i pojam Slavonije u XIII. stoljeću, Zagreb 2014 identifies Slavonia with the territory of Bishopric of Zagreb.

37 D. Bagi, "Sclavonia in der Ungarisch-Polnischen Chronik und die angeblichen slawischen Wurzeln des Arpadenreiches," Chronica 2016, vol. 12, pp. 57-68.

38 R. Grzesik, "Etnogeneza Słowian," Slavia Antiqua 2020, vol. 61, pp. 46-48. I do not analyse the question of the Slavic ethnogenesis here. 
The story of Adelaide follows the narration of the origins of the Hungarian state and creates a composition connection from pagan prehistory to the Christian past. We recognise that a grand-grand-son of Aquila/Attila, Yesse, married Adelaide, a sister of the Polish ruler Mieszko and the Princess of Cracow. She was a pious lady, who converted her husband and was a mother of St Stephen..$^{39}$ It is a great merit of Martin Homza, who analysed the literary topos of the mulieres suadentes, the women who converted their husbands. ${ }^{40}$ Adelaide as a literary creation belongs to such kind of personalities. I hesitated a long time how to interpret her biography. I started my research from a hypothesis that she was a real person and a mother of St Stephen. It was the opinion in a greater part of Polish historiography. But the study of sources falsified this hypothesis. I considered her a completely fictitious person, whose story was based on the Hungarian tradition. However, I started to suspect that Adelaide reflected a real person: the Polish wife of Béla I and a mother of St Ladislas. After a vivid discussion with Martin Homza, the proponent of historicity of Adelaide, who could be the real mother of St Stephen, I am sure that hypothesis created by Jerzy Dowiat and Tadeusz Wasilewski that it was Adelaide, mother of St Ladislas, is the only one solution of Adelaide question. ${ }^{41}$

There was still another question without an answer: why was she present in context of St Stephen's story, and not of the events from the time of Bolesław the Large and St Ladislas? This question led us to the final parts of the Chronicle, where the deeds of Polish Prince Bolesław were presented. He had the influential counsellor Sieciech, but was a son of Dambrouca. The knightly Polish ruler is a "mixture" of two persons with the same name Bolesław: the Brave and the Large. I thought that this mixture was possible only in Hungary. ${ }^{42}$ But after a longer research I have changed my mind and I think now that this was one of the stories derived from the Chronica Polonorum, the third source of our Chronicle. The story of Adelaide, the circumstances of the Polish-Hungarian rivalry for the crown, the description of the Polish-Hungarian borderland and a story of Bolesław could be derived from there. It was a narrative probably written for Salomea, when she married Coloman. The chronicle concentrated on the Polish-Hungarian relationship and was written in the milieu of the Cracow elites conducted the policy of rapprochement with Hungary. They were connected to the Principal court of Cracow and to the reform branch of the Church, they were also great adherents of canonization of St Stanislas, a previous bishop of Cracow murdered by Bolesław the Large.

I think that another, older narrative was used for the composition of the Chronica Polonorum. It was a chronicle described the deeds of Bolesław the Large (Gesta

39 HPC, pp. 21-22, 25-26.

40 M. Homza, Mulieres suadentes. Presviedčajúce ženy. Štúdie z dejín ženskej panovnickej svätosti v strednej a vo východnej Európe, v 10-13. storočí, Bratislava 2002.

${ }_{41}$ J. Dowiat, "Bela I węgierski w Polsce (1031/32-1048)," Przegląd Historyczny 1965, vol. 56, no. 1, pp. 1-23; T. Wasilewski, "Dwa utracone dawne roczniki: Rocznik biskupów dworu polskiego i Rocznik tyniecki (starszy)," Roczniki Historyczne 1988, vol. 54, pp. 1-61; R. Grzesik, Kronika, pp. 131-136.

42 R. Grzesik, Kronika, pp. 176-177. 
Boleslai Largi), from which the greater part of information was derived. However, the person of a ruler (presented as prince and not king yet), was perceived in more and more black colours, therefore it was impolitic to draw too positive image of the ruler. I think therefore that the authors made conscious forgery and tried to go the person of Bolesław II Large back into Bolesław I Brave's time. It would explain why Adelaide was a wife of Géza (Yesse), why the bishop of Cracow Lambert, living in the mid- $11^{\text {th }}$ century, went to Rome to Pope Leo (who in fact also reigned in the mid$11^{\text {th }}$ century), why Bolesław was the son of Dąbrówka, although Sieciech, who lived a hundred years after, was his main counsellor. This lost narrative about the deeds of Bolesław the Large seems to be the oldest Polish chronicle, which we know about. ${ }^{43}$

To conclude our remarks: 1) The Hungarian-Polish Chronicle is the compilation of three major narratives of Polish and Hungarian provenience and it connects Polish and Hungarian historical consciousness. 2) The story of Aquila as a founder of the Hungarian state and the biography of St Stephen constitute main motifs derived from the Hungarian tradition. It was completed by the story of murdered King, the product of the Great-Moravian tradition preserved by the Cyrillic-Methodian monasteries of the Slavic liturgy. 3) A narration about Adelaide, the Polish legacy to Rome to Pope Leo, Polish-Hungarian borderland and the saga of Bolesław is a product of a Polish source. 4) The Hungarian-Polish Chronicle is an important source for studies of the relationship between both countries.

\section{BIBLIOGRAPHY}

\section{Primary Sources Published}

Bartoniek E. (ed.), "Legenda sancti Stephani regis maior et minor atque Legenda ab Hartvico episcopo conscripta" [in:] Scriptores rerum Hungaricarum, vol. 2, ed. E. Szentpétery, Budapestini 1938, pp. 363-440.

Chronica Hungaro-Polonica, pars 1. (Textus cum varietate lectionum), ed. B. Karácsonyi, Szeged 1969 (Acta Historica Universitatis Szegedensis de Attila József nominatae, vol. 26.

Endlicher S.L., Rerum Hungaricarum Monumenta Arpadiana, Sangalli 1849.

Györffy Gy., Az Árpád-kori Magyarország történeti földrajza, vol. 3, Budapest 1987.

Homza M., Uhorsko-polská kronika. Nedocenený pramen̆ k dejinám strednej Európy, Bratislava 2009.

43 R. Grzesik, "Jeszcze jedna nieznana kronika polska z pierwszej połowy XIII w." [in:] Polska, Ruś i Węgry: X-XIV wiek, eds. D. Dąbrowski, A. Jusupović, T. Maresz, Cracow 2018, pp. 131-141 (text from 2014); idem, "Jedna lub dwie zaginione kroniki polskie z wczesnego średniowiecza" [in:] Stilo et animo. Prace historyczne ofiarowane Profesorowi Tomaszowi Jasińskiemu w 65. rocznice urodzin, eds. M. Dorna, M. Matla, M. Sosnowski, E. Syska, W. Baran-Kozłowski, Poznań 2016, pp. 67-76; idem, "Chronica Polonorum as One of the Basic Sources of the Hungarian-Polish Chronicle" [in:] Hadi és más nevezetes történetek. Tanulmányok Veszprémy László tiszteletére, ed. K.M. Kincses, Budapest 2018, pp. 157-162. 
Kownacki H., Kronika węgierska na początku wieku XII. Kronika czeska na początku wieku XI, w tacińskim języku pisane: z tłomaczeniem na Polski język. Tudzież Ziemopismo Bedy wieku VIII. List popa Jana wieku XIII z rękopismow rożnych bibliotek, Warszawa 1823.

Kronika węgiersko-polska, ed. S. Pilat, MPH, vol. 1, Lwów 1864, pp. 485-515.

Monumenta Poloniae Historica (MPH), vol. 1-6, Lwów-Cracow 1864-1893.

Szelestei L. N., “A seitzi legendárium Szent István-legendája,” Magyar Könyvszemle 1991, pp. 1-19.

\section{Literature}

Albrecht S., Drei neue Handschriften des sog. Chronicon hungarico-polonicum, Studia Źródłoznawcze 2015, vol. 53, pp. 111-121.

Albrecht S., Three New Manuscripts of the so Called Chronicon hungaro-polonicum, Hungaro-Polonica. Young Scholars on Medieval Polish-Hungarian Relations, ed. D. Bagi, G. Barabás, Zs. Máté, Pécs 2016, pp. 119-141.

Athleta Patriae. Tanulmányok Szent László történetéhez, ed. L. Mezey, Budapest 1980 (Hungaria Sacra, 1).

Bagi D., "Sclavonia in der Ungarisch-Polnischen Chronik und die angeblichen slawischen Wurzeln des Arpadenreiches," Chronica 2016, pp. 57-68.

Bali T., Slavonski meandar. Prostor i pojam Slavonije u XIII. stoljeću, Zagreb 2014.

Barna G., "Távolsági zarándoklatok és búcsújáró helyek az Árpád-kori Magyarországon," Honismeret 1991, no. 4, pp. 10-16.

Birkenmajerówna A., "Kownacki Tymoteusz Hipolit" [in:] Polski słownik biograficzny, vol. 14, ed. E. Rostworowski, Wrocław-Warszawa-Kraków 1968-1969, pp. 584-587.

Csákó J., “A Magyar-lengyel krónika és a hazai elbeszélő hagyomány," Századok 2014, no. 2, pp. 289-334.

Dowiat J., "Bela I węgierski w Polsce (1031/32-1048)," Przegląd Historyczny 1965, no. 1, pp. 1-23.

Font M., Barabás G., Koloman, King of Galicia and Duke of Slavonia (1208-1241), Amsterdam 2019.

Grzesik R., "Attyla a Słowianie. Przyczynek do wyobrażenia o kontaktach huńsko-słowiańskich w średniowiecznych źródłach narracyjnych,” Roczniki Historyczne 1993, vol. 59, pp. 33-42.

Grzesik R., "Chronica Polonorum as One of the Basic Sources of the Hungarian-Polish Chronicle" [in:] Hadi és más nevezetes történetek. Tanulmányok Veszprémy László tiszteletére, ed. K.M. Kincses, Budapest 2018, pp. 157-162.

Grzesik R., "Critical review of: Homza M., Pokus o interpretáciu úlohy kňažnej Adelajdy v Uhorsko-pol'skej kronike,” Historický časopis 1999, no. 3, pp. 357-382; Studia Źródtoznawcze 2000, vol. 38, pp. 125-127.

Grzesik R., "Etnogeneza Słowian w polskich kronikach średniowiecznych," Slavia Antiqua 2020, vol 61, pp. 41-51.

Grzesik R., "Great Moravia as the Basis of the Central European Medieval Historical Tradition" [in:] Slovensko a Chorvátsko. Historické paralely a vztahy (do roku 1780). Slovaćka i Hrvatska. Povijesne paralele i veze (do godine 1780), eds. M. Homza, J. Lukačka, N. Budak, Bratislava 2013, pp. 66-71.

Grzesik R., Hungaria - Slavia - Europa Centralis. Studia z dziejów kultury środkowoeuropejskiej we wczesnym średniowieczu, Warszawa 2014.

Grzesik R., "Jedna lub dwie zaginione kroniki polskie z wczesnego średniowiecza" [in:] Stilo et animo. Prace historyczne ofiarowane Profesorowi Tomaszowi Jasińskiemu w 65. 
rocznicę urodzin, eds. M. Dorna, M. Matla, M. Sosnowski, E. Syska, W. Baran-Kozłowski, Poznań 2016.

Grzesik R., "Jeszcze jedna nieznana kronika polska z pierwszej połowy XIII w.” [in:] Polska, Ruś i Węgry: X-XIV wiek, eds. D. Dąbrowski, A. Jusupović, T. Maresz, Kraków 2018, pp. 131-141.

Grzesik R., Kronika węgiersko-polska. Z dziejów polsko-węgierskich kontaktów kulturalnych w średniowieczu, Poznań 1999.

Grzesik R., "Sources of a Story About the Murdered Croatian King in the Hungarian-Polish Chronicle," Povijesni Prilozi 2003, Y. 22, vol. 24, pp. 97-104.

Grzesik R., "Tradycja tekstowa i rękopiśmienna Legend św. Stefana," Nasza Przeszłość 2016, vol. 125, pp. 127-145.

Györffy Gy., István király és müve, Budapest 1977 (and next eds. 1983, 2001).

Györffy Gy., King Saint Stephen of Hungary, New York 1994.

Györffy Gy., König Stephan der Heilige, Budapest 1988.

Historia Scepusii, vol. 1: Dejiny Spiša. Dzieje Spisza, eds. M. Homza, S.A. Sroka, Bratislava-Kraków 2009.

Homza M., Mulieres suadentes. Presviedčajúce ženy. Štúdie z dejín ženskej panovníckej svätosti v strednej a vo východnej Európe, v 10-13. storočí, Bratislava 2002.

Homza M., "Pokus o interpretáciu úlohy kňažnej Adelajdy v Uhorsko-pol'skej kronike," Historický časopis 1999, no. 3, pp. 357-382.

Homza M. et al., Svätopluk v európskom písomníctve. Štúdie z dejín svätoplukovskej legendy, Bratislava 2013.

Korai magyar történeti lexikon (9-14. század) (KMTL), eds. Gy. Kristó, P. Engel, F. Makk, Budapest 1994.

Nemet D., "Smrt hrvatskog kralja Zvonimira - problem, izvori i tumačenja," Radovi Zavoda za hrvatsku povijest u Zagrebu 2006, vol. 38, pp. 73-91.

"Stephan Ladislaus Endlicher" [in:] Österreichisches Biographisches Lexikon, vol. 1, Wien 1956, p. 249.

Tüskés A., "Szent Orsolya tisztelete a középkori Magyarországon: legendák, ereklyék, oltárok," Opus Mixtum 2014, pp. 34-49.

Veszprémy L., "A magyarországi hun hagyomány legkorábbi írott forrásai és európai kapcsolatuk," Acta Historica Universitatis Szegedensis de Attila József nominatae 2013, vol. 135 , pp. $25-44$.

Wasilewski T., "Dwa utracone dawne roczniki: Rocznik biskupów dworu polskiego i Rocznik tyniecki (starszy)," Roczniki Historyczne 1988, vol. 54, pp. 1-61.

Wiszniewski M., Historya literatury polskiéj, vol. 2, Kraków 1840. 